DOI: $10.17242 / M V v K \_30.04$

\title{
JELENTÉS A GÖNYÜ - SZOB KÖZTI DUNA-SZAKASZ (1791 - 1708 fkm) 2016. AUGUSZTUS - 2017. ÁPRILIS IDŐSZAKÁNAK VÍZIMADÁR FELMÉRÉSEIRŐL
}

\author{
REPORT ON THE WATERBIRD CENSUSES OF THE DANUBE RIVER BETWEEN \\ GÖNYÜ AND SZOB (River kms 1791-1708) DURING THE PERIOD AUGUST 2016 \\ AND APRIL 2017.
}

\section{Faragó Sándor}

\begin{abstract}
Magyar Vízivad Kutató Csoport, Soproni Egyetem Vadgazdálkodási és Gerinces Állattani Intézet Hungarian Waterfowl Research Group, Institute of Wildlife Management and Vertebrate Zoology, University of Sopron, H-9400 Sopron, Ady Endre u. 5., Hungary
\end{abstract}

\section{BEVEZETÉS}

Jelen dolgozat a MAGYAR VíziVAD MONITORING (MVvM) megfigyelési egységeként nyilvántartott Gönyü és Szob közötti Duna szakasza valamennyi vízimadárfajjal kibővített számlálásainak eredményeiről a 35. vizsgálati időszak alapján ad jelentést. A részletes előzmény összefoglalóját, illetve 30 év eredményeit FARAGÓ (2015a; 2016a) tette közzé, a megelöző négy szezon jelentései ugyancsak FARAGÓ (2015a; 2015b; 2016b; 2016c) közleményeiben olvashatók.

\section{ANYAG ÉS MÓDSZER}

A megfigyeléseket - a vizsgálatok 1982-es megindulása óta standardizált módon (FARAGÓ, 1996, 1997) - 2016 augusztusa és 2017 áprilisa között, havonta egy alkalommal az Északdunántúli Vízügyi Igazgatóság Atlasz-II. hajójáról végeztük. A korábbi tapasztalatoknak megfelelően, nem folytattunk megfigyelést május, június és július hónapokban. A megfigyelések száma a szezonban így hagyományosan 9 nap lett volna (kora öszi aspektus: 2016. augusztus 24., szeptember 21. - 2 nap; őszi aspektus: október 19., november 16. - 2 nap; téli aspektus: december 13., 2014. február 16. - 2 nap; tavaszi aspektus: március 13., április. 11 - alkalmazkodva a hajó kitüzési munkájához, de a januári erős jégzajlás miatt a januári felmérés elmaradt.

A számlálások eredményeit a 83 folyamkilométerre vonatkoztatva fajonként összesen, illetve 5 folyamkilométerre, mint sürüségegységre vonatkoztatva adjuk meg. A vízimadár állomány mennyiségét és fajösszetételét meghatározza a vízállás, ennek megfelelően megadjuk a vizsgált szakasz három vízmércéjén (Gönyü, Komárom és Esztergom) a megfigyelési napokon feljegyzett vízállásadatokat (1. táblázat).

1. táblázat: Vízállások napi adatai $(\mathrm{cm})$ a Gönyüi, komáromi és esztergomi vízmércéknél Table 1: Daily water level (cm) at the Gönyü, Komárom and Esztergom water gauges

\begin{tabular}{|l|c|c|c|c|c|c|c|c|c|}
\hline $\begin{array}{l}\text { Település } \\
\text { Settlement }\end{array}$ & $\begin{array}{c}\mathbf{2 0 1 6 .} \\
\text { aug. 24. }\end{array}$ & $\begin{array}{c}\text { 2016. } \\
\text { szept. 21. }\end{array}$ & $\begin{array}{c}\text { 2016. } \\
\text { okt. 19. }\end{array}$ & $\begin{array}{c}\text { 2016. } \\
\text { nov. 16. }\end{array}$ & $\begin{array}{c}\mathbf{2 0 1 6 .} \\
\text { dec. 13. }\end{array}$ & $\begin{array}{c}\text { 2017. } \\
\text { január }\end{array}$ & $\begin{array}{c}\mathbf{2 0 1 7 .} \\
\text { febr. 16. }\end{array}$ & $\begin{array}{c}\text { 2017. } \\
\text { márc. 13. }\end{array}$ & $\begin{array}{c}\mathbf{2 0 1 7 .} \\
\text { ápr. 11. }\end{array}$ \\
\hline Gönyü & 149 & 218 & 35 & 65 & 1 & $*$ & 5 & 216 & 83 \\
\hline Komárom & 210 & 256 & 107 & 175 & 75 & $*$ & 72 & 281 & 174 \\
\hline Esztergom & 196 & 204 & 85 & 134 & 61 & $*$ & 50 & 275 & 138 \\
\hline
\end{tabular}




\section{EREDMÉNYEK}

A számlálások eredményeit és a számított sürüségértékeket az 2. és 3. táblázat mutatja.

2. táblázat: A vízimadár számlálások eredményei (példány) a Duna Gönyü - Szob közti 83 km-es folyam-szakaszon a 2016/2017-es szezonban

Table 2: Results of waterbird censuses (number of birds) of $83 \mathrm{~km}$ long Danube section between Gönyü and Szob in the season 2016/2017

\begin{tabular}{|c|c|c|c|c|c|c|c|c|c|}
\hline Faj-Species & $\begin{array}{c}2016 . \\
\text { aug. } \\
24 .\end{array}$ & $\begin{array}{l}2016 . \\
\text { szept. } \\
21 .\end{array}$ & $\begin{array}{c}2016 . \\
\text { okt. } \\
19 .\end{array}$ & $\begin{array}{c}2016 . \\
\text { nov. } \\
16 .\end{array}$ & $\begin{array}{c}2016 . \\
\text { dec. } \\
13 .\end{array}$ & $\begin{array}{l}2017 . \\
\text { január }\end{array}$ & $\begin{array}{c}2017 . \\
\text { febr. } \\
16\end{array}$ & $\begin{array}{c}2017 . \\
\text { márc. } \\
13 .\end{array}$ & $\begin{array}{c}2017 . \\
\text { ápr. } \\
11 .\end{array}$ \\
\hline Cygnus olor & 2 & 4 & 5 & 23 & 43 & $*$ & 152 & 12 & 0 \\
\hline Anser anser & 0 & 0 & 0 & 0 & 71 & $*$ & 1002 & 2 & 0 \\
\hline Anser albifrons & 0 & 0 & 0 & 0 & 0 & $*$ & 3 & 0 & 0 \\
\hline Tadorna tadorna & 0 & 0 & 0 & 0 & 1 & $*$ & 2 & 0 & 0 \\
\hline Anas crecca & 0 & 0 & 0 & 0 & 0 & $*$ & 110 & 115 & 0 \\
\hline Anas platyrhynchos & 54 & 366 & 1042 & 3536 & 10230 & $*$ & 14137 & 256 & 40 \\
\hline Anas acuta & 0 & 0 & 0 & 0 & 0 & $*$ & 1 & 0 & 0 \\
\hline Anas clypeata & 0 & 0 & 0 & 0 & 0 & $*$ & 0 & 0 & 23 \\
\hline Aythya ferina & 0 & 0 & 0 & 0 & 0 & $*$ & 5 & 0 & 0 \\
\hline Aythya fuligula & 0 & 0 & 0 & 309 & 310 & $*$ & 493 & 52 & 0 \\
\hline Melanitta fusca & 0 & 0 & 0 & 0 & 1 & $*$ & 4 & 0 & 0 \\
\hline Bucephala clangula & 0 & 0 & 0 & 182 & 792 & $*$ & 2645 & 13 & 0 \\
\hline Mergellus albellus & 0 & 0 & 0 & 0 & 2 & $*$ & 23 & 0 & 0 \\
\hline Mergus merganser & 3 & 0 & 6 & 29 & 46 & $*$ & 93 & 1 & 4 \\
\hline Gavia arctica & 0 & 0 & 0 & 1 & 0 & $*$ & 0 & 0 & 0 \\
\hline Tachybaptus ruficollis & 0 & 0 & 0 & 0 & 1 & $*$ & 1 & 0 & 0 \\
\hline Podiceps cristatus & 0 & 0 & 0 & 3 & 1 & $*$ & 5 & 0 & 0 \\
\hline Phalacrocorax carbo & 40 & 169 & 409 & 538 & 660 & $*$ & 285 & 485 & 340 \\
\hline Microcarbo pygmeus & 0 & 0 & 0 & 0 & 0 & $*$ & 3 & 0 & 0 \\
\hline Egretta garzetta & 2 & 0 & 0 & 0 & 0 & $*$ & 0 & 0 & 2 \\
\hline Egretta alba & 0 & 1 & 15 & 6 & 40 & $*$ & 10 & 0 & 6 \\
\hline Ardea cinerea & 7 & 3 & 34 & 13 & 12 & $*$ & 4 & 64 & 84 \\
\hline Haliaeetus albicilla & 0 & 0 & 0 & 1 & 3 & $*$ & 4 & 3 & 4 \\
\hline Aquila heliaca & 0 & 0 & 0 & 0 & 0 & $*$ & 1 & 0 & 0 \\
\hline Fulica atra & 0 & 0 & 0 & 0 & 1 & $*$ & 6 & 0 & 0 \\
\hline Larus michahellis & 118 & 207 & 56 & 182 & 164 & $*$ & 853 & 52 & 10 \\
\hline Larus cachinnans & 0 & 0 & 0 & 3 & 0 & $*$ & 0 & 0 & 0 \\
\hline Larus argentatus & 0 & 0 & 0 & 0 & 0 & $*$ & 0 & 3 & 0 \\
\hline Larus canus & 19 & 24 & 4 & 27 & 81 & $*$ & 938 & 19 & 0 \\
\hline Hydrocoloeus minutus & 3 & 0 & 0 & 0 & 0 & $*$ & 0 & 0 & 0 \\
\hline Larus ridibundus & 173 & 131 & 334 & 132 & 390 & $*$ & 282 & 215 & 95 \\
\hline Sterna hirundo & 4 & 0 & 0 & 0 & 0 & $*$ & 0 & 0 & 0 \\
\hline Egyedszám - Number & 425 & 905 & 1905 & 4985 & 12849 & $*$ & 21062 & 1292 & 608 \\
\hline Fajszám - Sp.richness & 11 & 8 & 9 & 15 & 19 & $*$ & 25 & 14 & 10 \\
\hline \begin{tabular}{|l|} 
Shannon- H diverzitás \\
\end{tabular} & 1,577 & 1,443 & 1,226 & 1,113 & $\mathbf{0 , 8 8 9}$ & $*$ & 1,259 & 1,805 & $\mathbf{1 , 3 8 9}$ \\
\hline $\begin{array}{l}\text { Kiegyenlítettség - } \\
\text { Equitability }\end{array}$ & 0,658 & 0,694 & 0,558 & 0,411 & $\mathbf{0 , 3 0 2}$ & $*$ & 0,391 & 0,684 & 0,604 \\
\hline
\end{tabular}


3. táblázat: A vízimadár számlálások eredményei (sürüség - példány/5fkm) a Duna Gönyü Szob közti 83 km-es folyam-szakaszon a 2016/2017-es szezonban

Table 3: Results of waterbird censuses (density - number $/ 5 \mathrm{~km}$ ) of $83 \mathrm{~km}$ long Danube section between Gönyü and Szob in the season 2016/2017

\begin{tabular}{|c|c|c|c|c|c|c|c|c|c|}
\hline Faj-Species & $\begin{array}{c}2016 . \\
\text { aug. } \\
24 .\end{array}$ & $\begin{array}{l}2016 . \\
\text { szept. } \\
21 .\end{array}$ & $\begin{array}{c}2016 . \\
\text { okt. } \\
19 .\end{array}$ & $\begin{array}{c}2016 . \\
\text { nov. } \\
16 .\end{array}$ & $\begin{array}{c}2016 . \\
\text { dec. } \\
13 .\end{array}$ & $\begin{array}{c}2017 . \\
\text { január }\end{array}$ & $\begin{array}{c}2017 . \\
\text { febr. } \\
16\end{array}$ & $\begin{array}{l}2017 . \\
\text { márc. } \\
13 .\end{array}$ & $\begin{array}{c}2017 . \\
\text { ápr. } \\
11 .\end{array}$ \\
\hline Cygnus olor & 0,12 & 0,24 & 0,30 & 1,39 & 2,59 & $*$ & 9,16 & 0,72 & 0,00 \\
\hline Anser anser & 0,00 & 0,00 & 0,00 & 0,00 & 4,28 & * & 60,36 & 0,12 & 0,00 \\
\hline Anser albifrons & 0,00 & 0,00 & 0,00 & 0,00 & 0,00 & $*$ & 0,18 & 0,00 & 0,00 \\
\hline Tadorna tadorna & 0,00 & 0,00 & 0,00 & 0,00 & 0,06 & $*$ & 0,12 & 0,00 & 0,00 \\
\hline Anas crecca & 0,00 & 0,00 & 0,00 & 0,00 & 0,00 & $*$ & 6,63 & 6,93 & 0,00 \\
\hline Anas platyrhynchos & 3,25 & 22,05 & 62,77 & 213,01 & 616,27 & $*$ & 851,63 & 15,42 & 2,41 \\
\hline Anas acuta & 0,00 & 0,00 & 0,00 & 0,00 & 0,00 & $*$ & 0,06 & 0,00 & 0,00 \\
\hline Anas clypeata & 0,00 & 0,00 & 0,00 & 0,00 & 0,00 & * & 0,00 & 0,00 & 1,39 \\
\hline Aythy a ferina & 0,00 & 0,00 & 0,00 & 0,00 & 0,00 & $*$ & 0,30 & 0,00 & 0,00 \\
\hline Aythya fuligula & 0,00 & 0,00 & 0,00 & 18,61 & 18,67 & $*$ & 29,70 & 3,13 & 0,00 \\
\hline Melanitta fusca & 0,00 & 0,00 & 0,00 & 0,00 & 0,06 & $*$ & 0,24 & 0,00 & 0,00 \\
\hline Bucephala clangula & 0,00 & 0,00 & 0,00 & 10,96 & 47,71 & $*$ & 159,34 & 0,78 & 0,00 \\
\hline Mergellus albellus & 0,00 & 0,00 & 0,00 & 0,00 & 0,12 & $*$ & 1,39 & 0,00 & 0,00 \\
\hline Mergus merganser & 0,18 & 0,00 & 0,36 & 1,75 & 2,77 & $*$ & 5,60 & 0,06 & 0,24 \\
\hline Gavia arctica & 0,00 & 0,00 & 0,00 & 0,06 & 0,00 & * & 0,00 & 0,00 & 0,00 \\
\hline Tachybaptus ruficollis & 0,00 & 0,00 & 0,00 & 0,00 & 0,06 & $*$ & 0,06 & 0,00 & 0,00 \\
\hline Podiceps cristatus & 0,00 & 0,00 & 0,00 & 0,18 & 0,06 & $*$ & 0,30 & 0,00 & 0,00 \\
\hline Phalacrocorax carbo & 2,41 & 10,18 & 24,64 & 32,41 & 39,76 & $*$ & 17,17 & 29,22 & 20,48 \\
\hline Microcarbo pygmeus & 0,00 & 0,00 & 0,00 & 0,00 & 0,00 & $*$ & 0,18 & 0,00 & 0,00 \\
\hline Egretta garzetta & 0,12 & 0,00 & 0,00 & 0,00 & 0,00 & $*$ & 0,00 & 0,00 & 0,12 \\
\hline Egretta alba & 0,00 & 0,06 & 0,90 & 0,36 & 2,41 & $*$ & 0,60 & 0,00 & 0,36 \\
\hline Ardea cinerea & 0,42 & 0,18 & 2,05 & 0,78 & 0,72 & $*$ & 0,24 & 3,86 & 5,06 \\
\hline Haliaeetus albicilla & 0,00 & 0,00 & 0,00 & 0,06 & 0,18 & * & 0,24 & 0,18 & 0,24 \\
\hline Aquila heliaca & 0,00 & 0,00 & 0,00 & 0,00 & 0,00 & $*$ & 0,06 & 0,00 & 0,00 \\
\hline Fulica atra & 0,00 & 0,00 & 0,00 & 0,00 & 0,06 & $*$ & 0,36 & 0,00 & 0,00 \\
\hline Larus michahellis & 7,11 & 12,47 & 3,37 & 10,96 & 9,88 & $*$ & 51,39 & 3,13 & 0,60 \\
\hline Larus cachinnans & 0,00 & 0,00 & 0,00 & 0,18 & 0,00 & $*$ & 0,00 & 0,00 & 0,00 \\
\hline Larus argentatus & 0,00 & 0,00 & 0,00 & 0,00 & 0,00 & $*$ & 0,00 & 0,18 & 0,00 \\
\hline Larus canus & 1,14 & 1,45 & 0,24 & 1,63 & 4,88 & $*$ & 56,51 & 1,14 & 0,00 \\
\hline Hydrocoloeus minutus & 0,18 & 0,00 & 0,00 & 0,00 & 0,00 & $*$ & 0,00 & 0,00 & 0,00 \\
\hline Larus ridibundus & 10,42 & 7,89 & 20,12 & 7,95 & 23,49 & $*$ & 16,99 & 12,95 & 5,72 \\
\hline Sterna hirundo & 0,24 & 0,00 & 0,00 & 0,00 & 0,00 & $*$ & 0,00 & 0,00 & 0,00 \\
\hline $\begin{array}{l}\text { Összes sürüség - } \\
\text { Total density }\end{array}$ & 25,60 & 54,52 & 114,76 & 300,30 & 774,04 & $*$ & 1268,80 & $\mathbf{7 7 , 8 3}$ & 36,63 \\
\hline
\end{tabular}

A legnagyobb példányszámot $(\mathrm{n}=21062)$ februárban rögzítettük, míg a legkevesebb madarat augusztusban $(n=425)$ számláltunk. Előbbi esetben a telelésre érkező madarakkal dúsult fel- a jégzajlás után - a folyó, utóbbiban tulajdonképpen csak azt itt fészkelöket lehetett látni. 
A megfigyelt fajszám februárban (tehát ugyancsak télen) volt a legmagasabb (25 faj), szeptemberben pedig csak 8 fajt láttunk. A 8 észlelés során egyébként 32 fajt figyelhettünk meg.

Az alkalmi megjelenésű, vagy kis létszámmal (esetenként $<100$ pd) előforduló fajok az Anser albifrons (max. 3 pd), a Tadorna tadorna (max. 2 pd), az Anas acuta (max. 1 pd), az Anas clypeata (max. 23 pd), az Aythya ferina (max. 5 pd), a Melanitta fusca (max. 4 pd), a Mergellus albellus (max. 23 pd), a Mergus merganser (max. 93 pd), a Gavia arctica (max. 1 pd), a Tachybaptus ruficollis (max. 1 pd), a Podiceps cristatus (max. 5 pd), a Microcarbo pygmeus (max. 3 pd), az Egretta garzetta (max. 2 pd), az Egretta alba (max. 40 pd), a Haliaeetus albicilla (max. 4 pd), az Aquila heliaca (max. 1 pd), a Fulica atra (max. 6 pd), a Larus cachinnans (3 pd), a Larus argentatus (3 pd), a Hydrocoloeus minutus (max. $3 \mathrm{pd}$ ) és a Sterna hirundo (max. 4 pd) voltak.

A nagyobb létszámú (esetenként $>100$ pd) fajok esetében részletesebb elemzést is adunk.

- Bütykös hattyú (Cygnus olor) - A kora ősz és az ősz folyamán lassan növekedett észlelt példányszáma, ami decemberben elérte a 43 pd-t. Tetőzése februárban volt 152 pd-nyal, majd gyorsan eltünt a Dunáról. Áprilisban nem észleltük (1. ábra).

- Nyári lúd (Anser anser) - A faj december és március között jelent meg a Dunán, általában kis példányszámmal. Kivételt képezett 2017 februárja, amikor 1002 pd repült el a folyamszakasz mentén.

- Csörgö réce (Anas crecca) - Csak tél végén és tavasz elején észleltük (febr.: 110 pd; márc.: $115 \mathrm{pd})$.

-Tőkés réce (Anas platyrhynchos) - A megfigyelt mennyiség 40-14 137 pd volt. A nyár végi egyedszám $(54 \mathrm{pd})$ fokozatos, egyenletes feldúsulása következett be a februári tetőzésig. Megjegyzendő itt is, hogy a januári jégzajlások miatt abban a hónapban nem volt számlálás. Február után gyors elvonulás volt észlelhető, majd már csak a megkésettek és a környéken fészkelők maradtak (1. ábra). Az összes megfigyelt tőkés réce (n=29 661 pd) egyébként viszonylagosan egyenletes eloszlása mellett a legnagyobb koncentrációk Süttő és Nyergesújfalu térségében voltak észlelhetők (2. ábra).

- Kárókatona (Phalacrocorax carbo) - A megfigyelt mennyiség 40-660 pd volt. A nyár végi egyedszám (40 pd) folyamatosan növekedett a decemberi, téli tetőzésig (660 pd). Ezt követően februárban és márciusban némileg alacsonyabb szinten állandósult létszáma (285 és 485 pd). A márciustól csökkent létszámuk, amely áprilisban 340 pd volt. A kárókatonának a vizsgált Duna szakaszon 3 fészektelepe ismert, ahol 2017-ben becslésünk szerint 235-250 pár fészkelt (Zsidó-sziget: 95-100 pár, Süttői-sziget: 95-100 pár, Helemba-sziget: 45-50 pár), ami kevesebb az előző évinél (310-320 pár). Az összes megfigyelt kárókatona ( $\mathrm{n}=2926$ pd) eloszlása alapján a legnagyobb koncentrációk Szob, Dunaalmás, Süttő, Nyergesújfalu, Szőny és Ács térségében voltak észlelhetők (2. ábra).

- Kerceréce (Bucephala clangula) - A megfigyelt mennyiség 0-2645 pd volt, november és március között volt jelen a Dunán. Megérkezése után folyamatosan nőtt létszáma februárig (2645 pd), majd drasztikus létszámcsökkenés után, márciusban már csak kis példányszámmal (13 pd) volt jelen a folyón. Áprilisra eltűnt a Dunáról (1. ábra). Az összes megfigyelt kerceréce $(\mathrm{n}=3632$ pd) eloszlása alapján a legnagyobb koncentrációk Süttő, Nyergesújfalu Esztergom és Szob térségében voltak észlelhetők. Hagyományosan a Süttő alatti folyamszakaszon nagyobb a létszáma (2. ábra).

- Dankasirály (Larus ridibundus) - A megfigyelt mennyiség 95-390 pd volt. A nyár végi 173 pd-os induló létszám - októberi átmeneti emelkedés (334 pd) után - decemberre 390 pdra növekedett, majd februárra 282 pd-ra csökkent. Ebben a szezonban elmaradt a tavaszi feldúsulás, márciusban a madarak zöme elvonult fészkelni (maradt 215 pd), s kis mennyiségü kóborló, táplálkozó példány volt látható áprilisban (95pd) (1. ábra). Az összes megfigyelt 


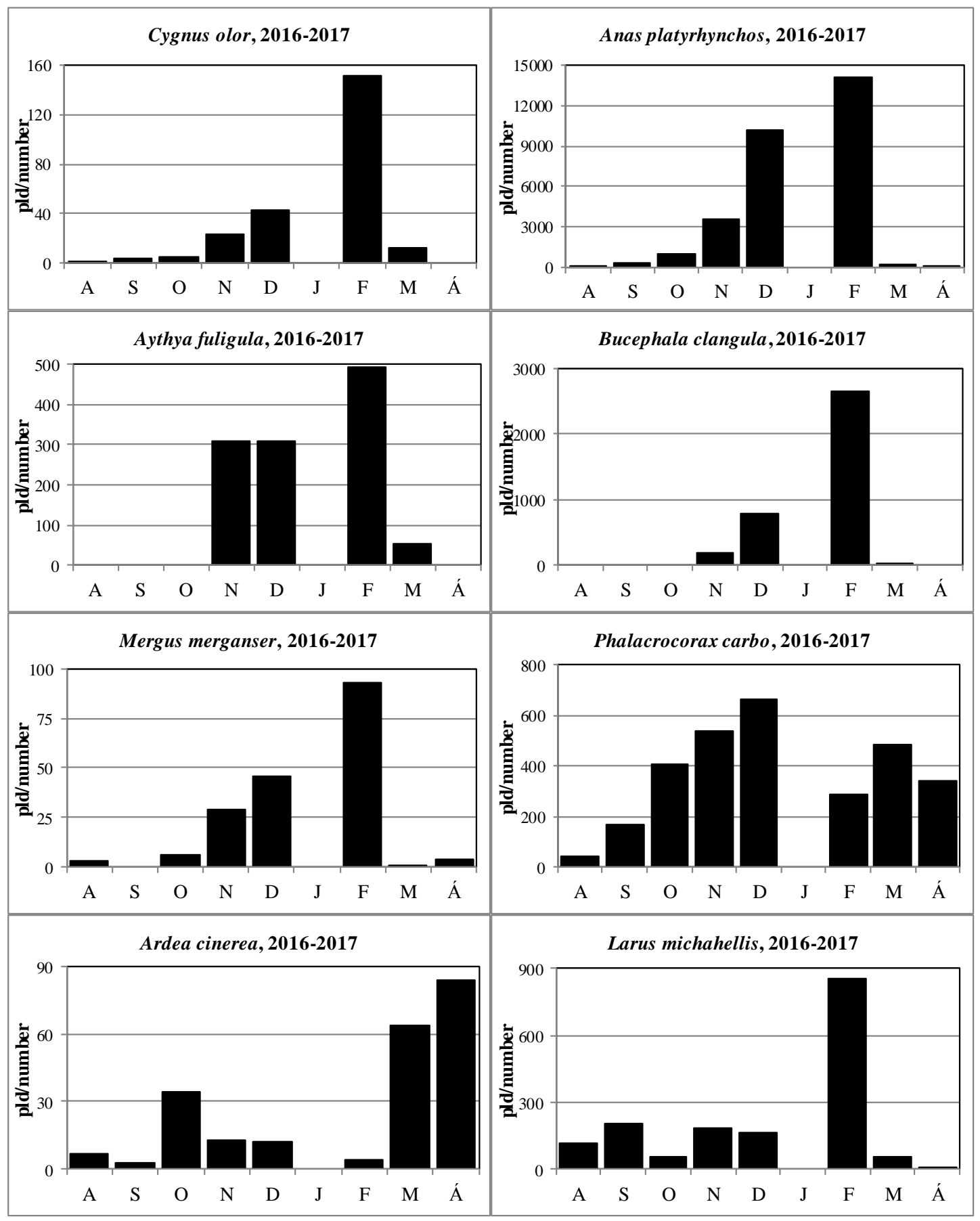

1. ábra: A domináns vízimadárfajok dinamikája 2016/2017-es szezonban Figure 1: Dynamics of dominant waterbird species in the season 2016/2017

dankasirály ( $\mathrm{n}=1752$ pd) eloszlása alapján legnagyobb gyülekezőhelyei - együtt a sárgalábú sirállyal - Almásfüzitő, Szob, továbbá Dunaalmás és Esztergom térségének zátonyainál, kőzárásainál, valamint vonulásuk során a nyílt föágakon voltak (2. ábra).

- Kontyos réce (Aythya fuligula) - A megfigyelt mennyiség 0-493 pd volt, november és március között volt jelen a Dunán. Megérkezése után decemberig 309-310 pd-ban lehetett észlelni, majd februárban érte maximumát (493 pd). Márciusban már csak $52 \mathrm{pd}$ maradt belőle, s ezt követően végleg elvonult (1. ábra). Hasonló élöhelyeken, szakaszon volt található, mint a kerceréce. 
- Sárgalábú sirály (Larus michahellis) - A megfigyelt mennyiség 10-853 pd volt. Öszi és tél eleji előfordulása 56-207 pd között változott, majd a maximumot februárban észleltük (853 pd), ami erős visszaesés után márciusra 52 pd-ra, áprilisra 10 pd-ra csökkent (1. ábra). Az összes megfigyelt sárgalábú sirály ( $\mathrm{n}=1642$ pd) eloszlása alapján legnagyobb gyülekezőhelyei Almásfüzitő, Dunaalmás és Szob zátonyainál, kőzárásainál voltak (2. ábra).

Bár korábban a kisebb létszámú fajoknál szoktuk felsorolni a viharsirályt (Larus canus), ebben a szezonban azonban - a korábbi idényhez hasonlóan - kiemelkedően magas megjelenését észleltük februári vonulása során (938 pd) (1. ábra), de diszperziójáról ugyanazt mondhatjuk el, mint a másik két sirályfaj esetében.

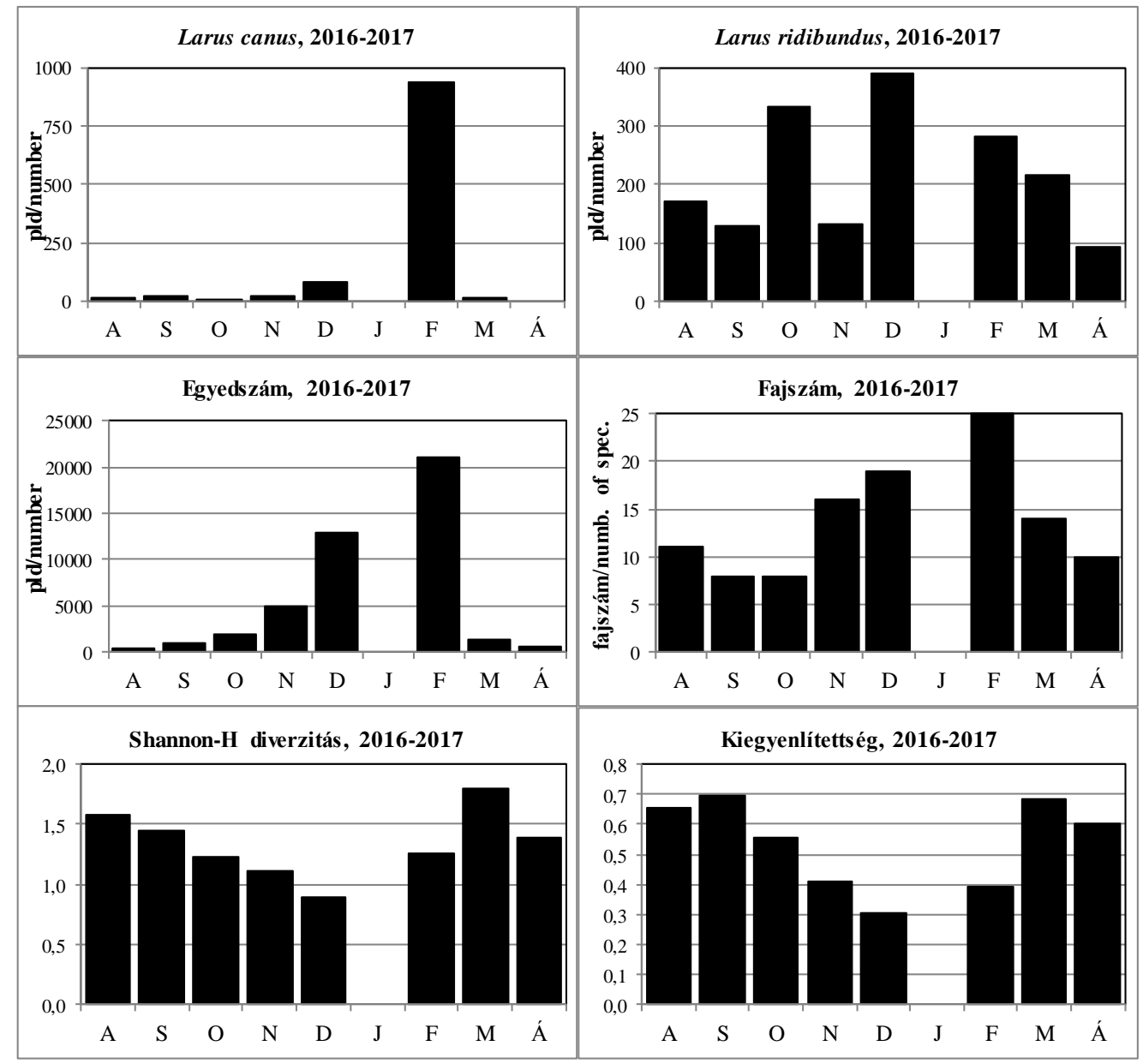

1. ábra (folyt.): A domináns vízimadárfajok dinamikája 2016/2017-es szezonban Figure 1 (cont.): Dynamics of dominant waterbird species in the season 2016/2017

A bütykös hattyú (Cygnus olor) a korábbi évhez (max. 71 pd) képest is nagyobb létszámban (max 152 pd) fordult elő e Duna szakaszon (1. ábra), amit a jeges január koncentráló hatásával magyarázhatunk.

A ritkább fajok közül fészkelése okán megemlítendő a szürke gém (Ardea cinerea), amely a kárókatonával együtt ugyancsak 3 telepen fészkelt, 2017-ben becslésünk szerint 115124 párban (Zsidó-sziget: 40-43 pár, Süttői-sziget: 60-65 pár, Helemba-sziget: 15-16 pár), ami lényegesen alacsonyabb a 2016-os fészkelö pár (212-215 pár) számnál.

A rétisasnak (Haliaeetus albicilla) két ismert fészke (Nagy-Erebe-sziget és Mocsisziget) lakott volt 2017-ben is. 

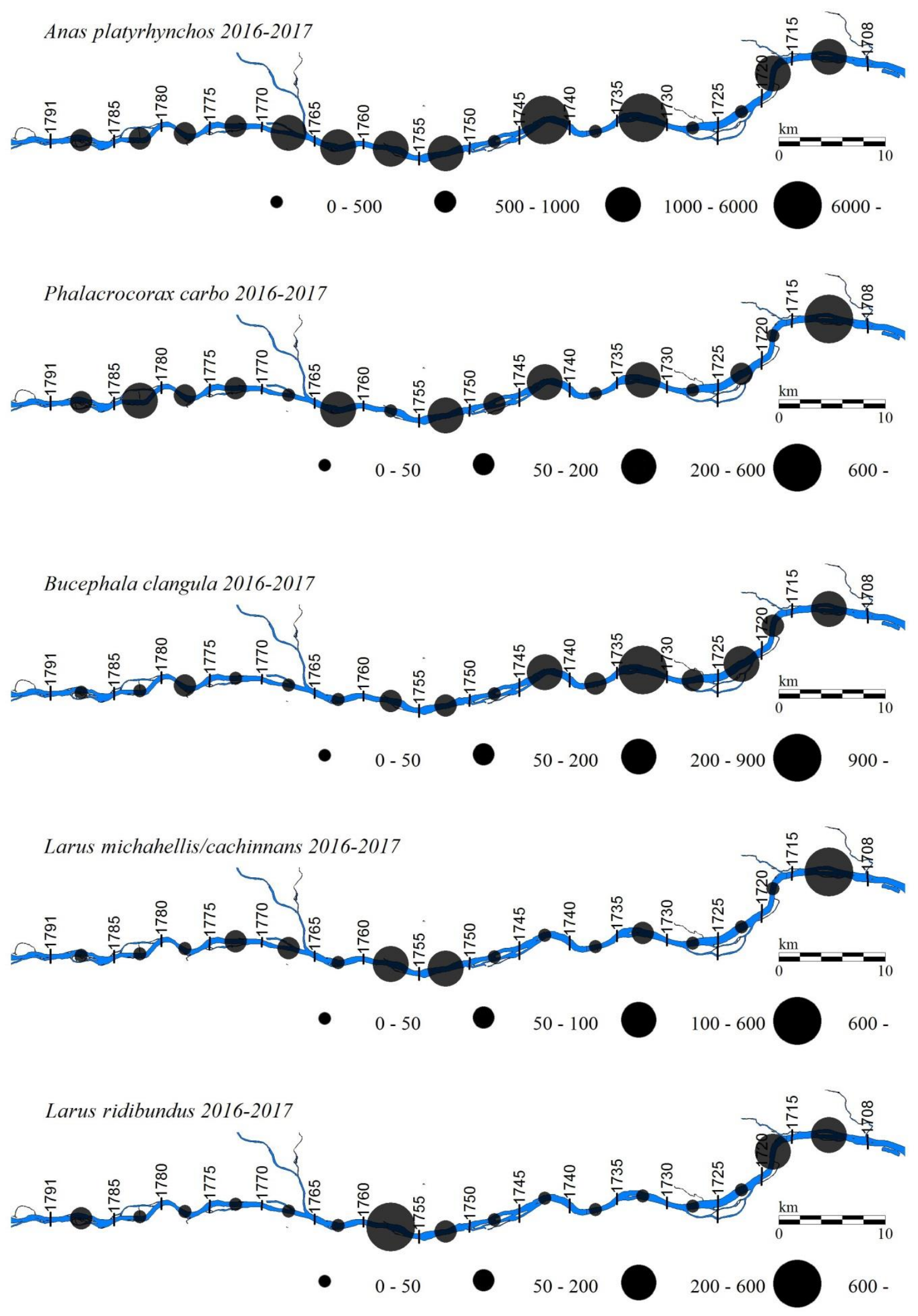

2. ábra: Az öt leggyakoribb vízimadárfaj diszperziója

Figure 2: The dispersion of five top waterbird species 


\section{EGYÉB MEGFIGYELÉSEK}

2016. november 15-én az 1786-os folyam km-nél (Gönyü) parti fán ülő 1 pd vándorsólyom (Falco peregrinus) került megfigyelésre, 2016. december 13-án pedig 2 pd kormos varjú (Corvus corone) észlelése történt.

\section{KÖSZÖNETNYILVÁNÍTÁS}

Köszönöm Dr. HADARICS TIBORnak a megfigyelések során nyújtott segítségét.

\section{IRODALOMJEGYZÉK}

FARAGó, S. (1996): A Duna Gönyü - Szob közti szakasza (1791-1708 fkm) vízimadár állományának 10 éves (1982-1992) vizsgálata. Magyar Vizivad Közlemények 1: 1-461.

FARAGÓ, S. (1997): The methodology used for the long-term monitoring of water birds in a large river. The Danube River between Gönyü and Szob (river kms 1791-1708) in Hungary, a case study. In: FARAGÓ, S. \& KEREKES, J. J. (Eds.): Limnology and Waterfowl. Monitoring, Modelling and Management. Proceedings of a Symposium on Limnology and Waterfowl, Sopron/Sarród, Hungary, November 21-23, 1994. Magyar Vizivad Közlemények 3 - Wetlands International Publication 43: 31-41.

FARAGÓ, S. (2015a): Jelentés a Gönyü - Szob közti Duna-szakasz (1791 - 1708 fkm) 2012. augusztus - 2013. április időszakának vízimadár felméréseiről. Magyar Vizivad Közlemények 26: 169-178. http://dx.doi.org/10.17242/MVvK_26.02

FARAGÓ, S. (2015b): Jelentés a Gönyü - Szob közti Duna-szakasz (1791 - 1708 fkm) 2013. augusztus - 2014. április időszakának vízimadár felméréseiről. Magyar Vízivad Közlemények 26: 179-185. http://dx.doi.org/10.17242/MVvK 26.03

FARAGÓ, S. (2016a): A Duna a Gönyü-Szob közti szakasza vonuló vízimadár-állományának 30 éves (1982-2012) vizsgálata. Nyugat-magyarországi Egyetem Kiadó, Sopron, 494 p.

FARAGÓ S. (2016b): Jelentés a Gönyü-Szob közti Duna-szakasz (1791-1708fkm) 2014. augusztus - 2015. április időszakának vízimadár felméréseiről. Magyar Vízivad Közlemények 28: 257-264. http://dx.doi.org/10.17242/MVvK_28.07

FARAGÓ S. (2016c): Jelentés a Gönyü-Szob közti Duna-szakasz (1791-1708fkm) 2015. augusztus - 2016. április időszakának vízimadár felméréseiről. Magyar Vizivad Közlemények 28: 265-272. http://dx.doi.org/10.17242/MVvK_28.08

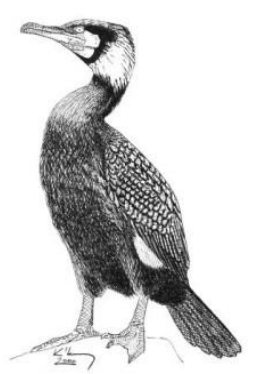




\title{
REPORT ON THE WATERBIRD CENSUSES OF THE DANUBE RIVER BETWEEN GÖNYÜ AND SZOB (River kms 1791-1708) DURING THE PERIOD AUGUST 2016 AND APRIL 2017.
}

\author{
Faragó, S.
}

\section{SUMMARY}

Based on the results of the waterfowl counts (shown in Tables 2 and 3) completed during the 2016/2017 season in the section between Gönyü and Szob of the Danube river, we recorded the largest number of waterbirds $(n=21062)$ in February, while the smallest total number of birds occurred in August ( $\mathrm{n}=425)$. The daily water level of observations shows Table 1.

We observed the highest number of species (25 species) in February, while in September and October we saw only 8 species. During the 8 -month study, we observed 32 species.

Species that only appeared occasionally or in small numbers $(<100$ per observation) included Anser albifrons (max. 3 ind.), Tadorna tadorna (max. 2 ind.), Anas acuta (max. 1 ind.), Anas clypeata (max. 23 ind.), Aythya ferina (max. 5 ind), Melanitta fusca (max. 4 ind.), Mergellus albellus (max. 23 ind), Mergus merganser (max. 93 ind.), Gavia arctica (max. 1 ind.), Tachybaptus ruficollis (max. 1 ind.), Podiceps cristatus (max. 5 ind.), Microcarbo pygmeus (max. 3 ind.), Egretta garzetta (max. 2 ind.), Egretta alba (max. 40 ind.), Haliaeetus albicilla (max. 4 ind.), Aquila heliaca (max. 1 ind.), Fulica atra (max. 6 ind.), Larus cachinnans (3 ind.), a Larus argentatus (3 ind.), Hydrocoloeus minutus (max. 3 ind.) and Sterna hirundo (max. 4 ind.).

Species that appeared in larger numbers and quantities ( $>100$ per observation) were as follows: Anas platyrhynchos: 40-14 137, Phalacrocorax carbo: 40-660, Bucephala clangula: 0-2645, Larus ridibundus: 95-390, Larus canus: 0-938, Aythya fuligula: 0-493 and Larus michahellis: 10-853. Figures 1 and 2 present the dynamics and frequency dispersion of common species.

There are 3 known Great Cormorant (Phalacrocorax carbo) nesting colonies in the studied section of the Danube; in 2017, 235-250 pairs nested there. There were 115-124 pairs of Grey Heron (Ardea cinerea) which, like the Great Cormorant, also nests in 3 colonies.

There are also two known White-tailed Eagles (Haliaeetus albicilla) nests in the section of the Danube (Nagy-Erebe Island and Mocsi Island); booth nest were inhabited in 2017 and breeding were as well. 
